doi:10.5937/jaes9-1120

Paper number: 9(2011)4, 208, 437 - 448

\title{
REVIEW OF THE CURRENT WIND ENERGY TECHNOLOGIES AND GLOBAL MARKET
}

\author{
Mr Dragan Komarov * \\ University of Belgrade, Faculty of Mechanical Engineering, Belgrade, Serbia \\ Dr Slobodan Stupar \\ University of Belgrade, Faculty of Mechanical Engineering, Belgrade, Serbia \\ MSc Zorana Posteljnik \\ University of Belgrade, Faculty of Mechanical Engineering, Belgrade, Serbia
}

The modern wind energy technologies and recent global wind energy market trends are reviewed in the paper. Basic principles of conversion of wind energy to electricity are described with brief overview of the state-of-the-art technologies for subassemblies such as wind turbine blades and drivetrains. Global wind energy market was reviewed in order to attain notion of wind power market developments in the future. The most developed countries in terms of wind energy utilization such as Denmark, Germany, Spain and USA were identified as the key drivers of wind energy technology advances. After the long leadership of European Union in built annual wind power capacities, China and USA have overtook leading positions for the last several years. Wind energy costs per unit of electricity produced after gradual decrease until 2005 have recorded slight increase until the present due to high demand and higher raw materials price. It was predicted that the trend of the wind energy cost will decrease in the future. Steady growth of wind energy capacities was predicted in the next years, with forecast that present global installed capacities of nearly $200 \mathrm{GW}$ should grow to almost one terawatt by the 2020.

Key words: capacity, energy use, globalization, markets, technology, wind turbine, wind energy, winds

\section{INTRODUCTION}

Energy demand had rapid growth in the last century. The gross energy needs were supplied by conventional energy resources such as coal and oil, as well as newer technologies such as nuclear power plants. High demand and limited resources had influence on the price growth of the produced electricity. Environmental issues, economy and political factors have influenced on renewable energy growth in the last thirty years. Due to large quantity of $\mathrm{CO} 2$ emissions from power and heavy industries, as well as traffic, the social awareness have risen of induced climate change. After the oil crisis in 1970s, the interest in renewable energy was growing. Relatively simple design and existing technologies developed mainly for aeronautical and power-generation purposes made wind energy industry one of the fastest growing in the following decades [09]. As technology has matured, wind energy grew to substantial capacity [19], [23]. Although this capacity is still incomparabletothetotal installed powerintheworld [12], wind energy presents industry that should not be neglected in the recent period and in the future. After the brief introduction, the review of the current wind turbine technologies was given with emphasis on commercial design. Technology trends and novel concepts of some assemblies were also given in this section. Overview of global wind energy capacities was given with brief summary of the most developed markets as well as emerging ones in the next section. Wind energy costs were described in the following section with breakdown of the costs due to initial investment, operation and maintenance and other costs. Short conclusions were given at the end of the paper.

\section{WIND TURBINE DESIGN CONCEPTS}

Wind turbine design has been changing over the years, from being convention-driven to being optimized-driven. As well as becoming larger (the generators in the largest modern wind turbines are 100 times the size of those in 1980), 
wind turbine designs have been progressing from fixed-speed, stall-controlled to pitch-controlled, variable speed, with or without gearboxes. Other improvements include the use of different combinations of composite materials to manufacture blades, especially to ensure that their weight is kept to a minimum, as well as modern control system for better compatibility with the grid connection. Some of the design drivers for current wind turbine technology are reliability, grid compatibility, maximum efficiency, noise reduction, high productivity for low wind speeds, aerodynamic performance, etc. Even though much time and resources are continuously spent on improving the wind technology since its commercial beginnings in the early 1980s, the basic architecture of the mainstream design has maintained its original topology. Wind power technologies can be grouped in three applications:

- Large grid connected wind turbines,

- Small "stand-alone" wind turbines for water pumping, battery charging, heating, etc.

- Hybrid energy systems - wind turbines in combination with other energy sources.

Generally, wind turbines can be classified, according to the axis of rotation of main shaft, as horizontal axis wind turbines (HAWT) and vertical axis wind turbines (VAWT), the first being dominate in wind power large-scale utilization, figure 1. HAWTs are usually classified according to the rotor orientation relative to wind direction (upwind or downwind), hub design (rigid or teetering), rotor control (pitch vs. stall), rotor speed (fixed or variable), number of blades, their alignment with the wind direction (active or passive yaw). HAWTscan use differentnumberofblades, depending on the purpose of the wind turbine. The determination of the number of blades involves design considerations of aerodynamic efficiency, component costs and system reliability, as well as aesthetics.

The loads on wind turbine rotor are cyclic depending on blade position during the operation. Cyclic loads when combined together at the drivetrain shaft are symmetrically balanced for three blades, [06]. Modern utility-scale wind turbines usually have three-bladed upwind rotor and are actively yawed to preserve alignment with the wind direction. Although the length of the blade can be as long as $60 \mathrm{~m}$, blades of the rotor are commonly manufactured as one part using different techniques for composite manufacturing. Still, one of the world's largest wind turbines, the Enercon E126 , adopts a jointed blade design. In the E-126

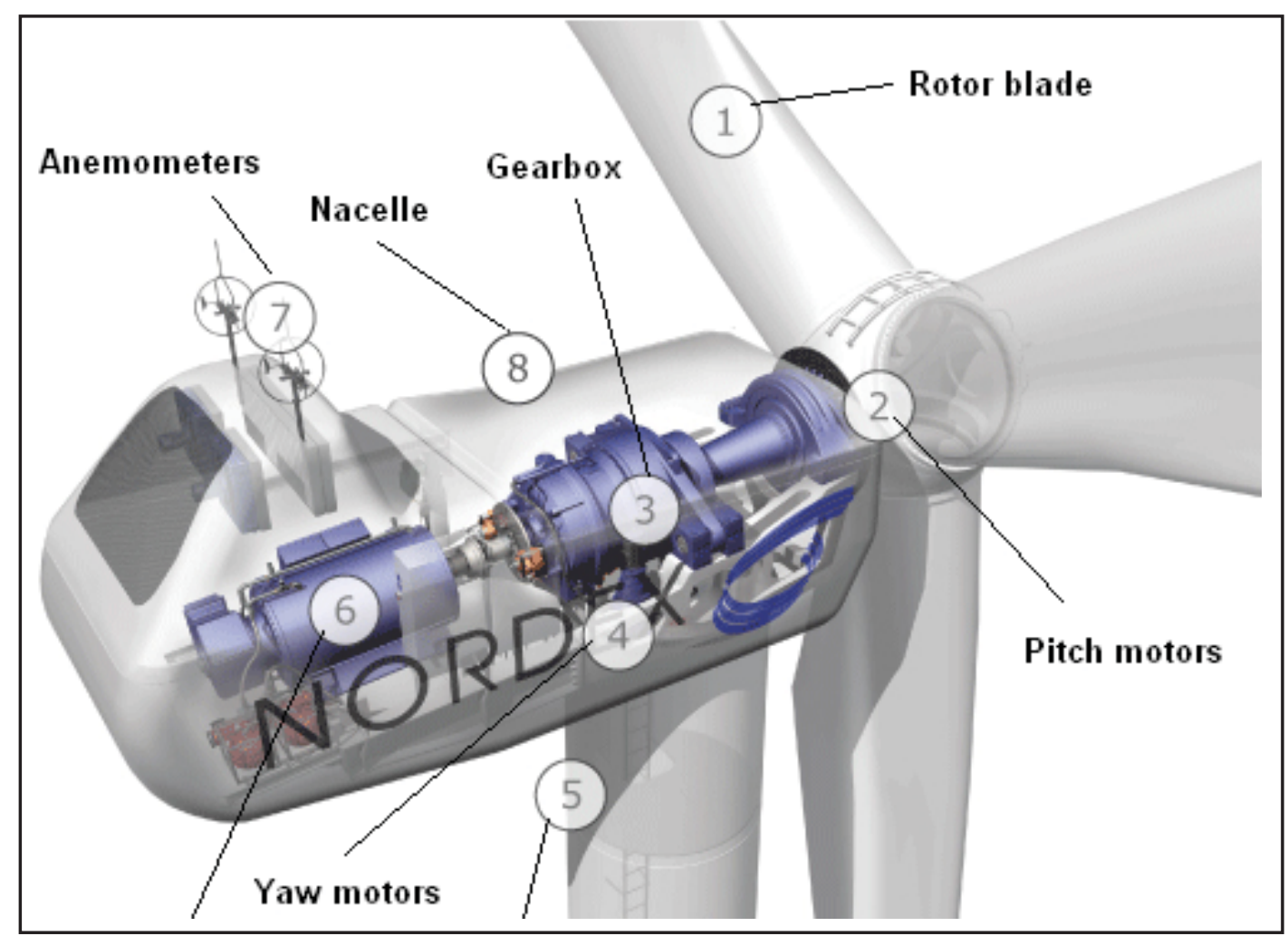

Figure 1. Main components of a horizontal axis wind turbine [13] 
blade, an outer blade section with a conventional blade root attachment is bolted to a steel inner blade spar. The trailing edge of the inner blade is a separate composite structure. Gamesa has also developed a jointed blade design for the G10X wind turbine. The rotor size will increase in the future, as the trend of manufacturing of the larger multi-megawatt wind turbines will not cease. Beside the reason for the manufacturing of larger blades due to demand for megawatt machines in the range between 3 and 7 megawatts, larger rotors would enable higher energy yield at sites with lower wind speeds. For example, Nordex has revealed the wind turbine with 117 meter rotor diameter with $2.4 \mathrm{MW}$ rated power.

It is claimed that this wind turbine could achieve 3500 full-load hours at typical inland locations, which corresponds to capacity factor around 40 percent, which makes it feasible for construction in lower wind speed sites. In order to attain technology necessary for manufacturing and operation of wind turbines with very long blades (longer than $100 \mathrm{~m}$ ) it is necessary to develop stronger and lighter materials, to reduce loads using advanced flexible materials and novel concepts of blade operation control, to use innovative technologies for wind speed measurements etc. With these innovations, it is believed that 20 MW wind turbine will be feasible in the future [08].

The rotation of the blades is transferred through the drivetrain on to the generator, creating electricity. At the wind speeds between 10 and 15 $\mathrm{m} / \mathrm{s}$, the power output of wind turbine rotor usually reaches its rated capacity. If the rated wind speed is exceeded the power has to be limited, to prevent wind turbine from overloading and to ensure that it has constant output. There are two principal means of limiting rotor power in high operating wind speeds - stall regulation and pitch regulation. Stall-regulated machines require a constant rotational speed which can be achieved with a grid-connected induction generator. As wind speed increases and the rotor speed is held constant, flow angles over the blade sections increase. The blades become increasingly stalled and this limits power to acceptable levels, without any additional active control. On the other hand, using pitch regulation the blades have additional degree of freedom around their longitudinal axis so that the aerodynamic characteristics of the blade - and the rotor - can be controlled. In contrast to stall regulation, pitch regulation requires changes of rotor geometry by pitching the blades. This involves an active control

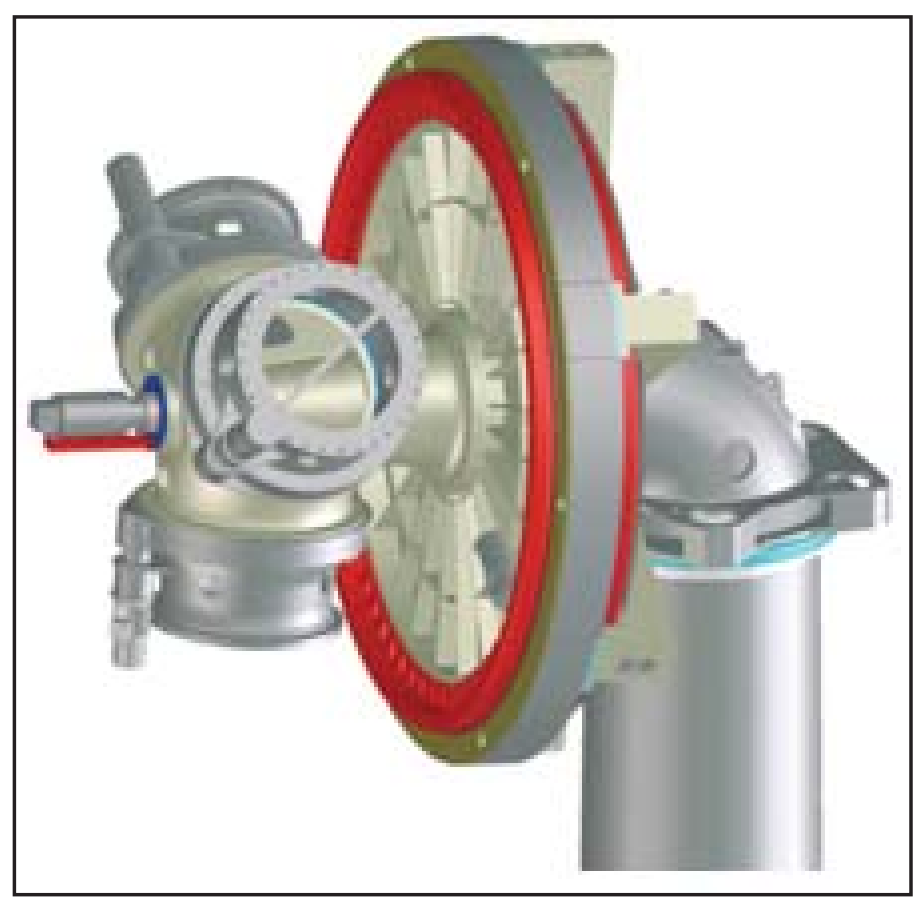

Figure 2. Direct drive of Enercon E-48 [17] 
system, which senses blade position, measures output power and instructs appropriate changes of blade pitch [01]. Modern large-scale wind turbines are almost exclusively pitch-regulated. As it was mentioned, the drivetrain contains the rotor attached to a main shaft driving the generator through the optional gearbox. However,

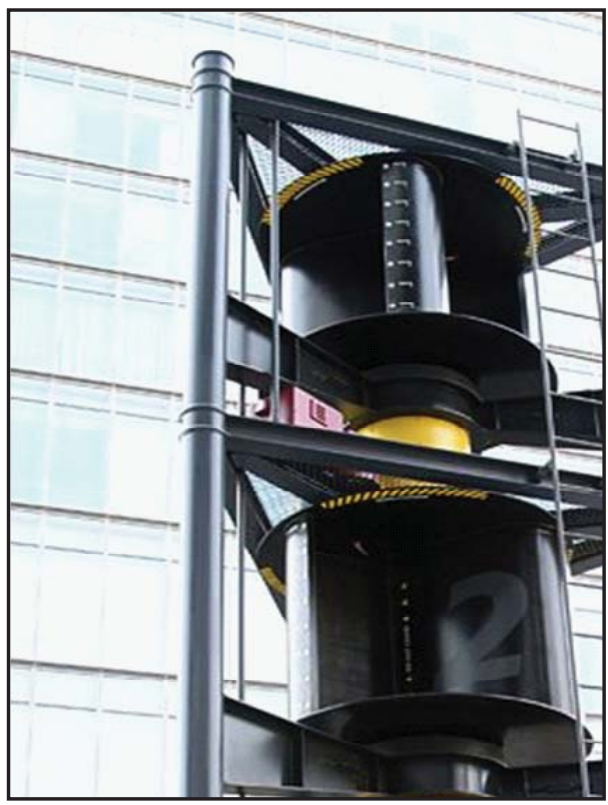

there are many significant variations in structural support, in rotor bearing system and in general layout. Vestas adopted the large single front bearing arrangement in the V90 $3 \mathrm{MW}$ design, which contributed to a very compact and lightweight nacelle system. Also, there has been a significant trend towards innovative drivetrain

Figure 3. Savonius and Darrieus type of VAWT

systems. There are companies that use directly driven variable speed synchronous generators with large-diameter synchronous ring generator (figure 2.), but majority of wind turbine manufacturers still use six-pole induction (asynchronous) generators connected through a gearbox to a rotor. Induction generators have a softer connection to the network frequency than synchronous generators, which reduce the loads between rotor and generator during wind gusts.

Low overall efficiency during low speed winds can be overcome using two induction generators, smaller and larger one. The motivation for direct drive application is to simplify the nacelle systems, increase reliability, increase efficiency and avoid gearbox issues. Enercon and Siemens established the direct drive system, as well as some other manufacturers like Vensys, whose wind turbines are based on the generator concept of a synchronous machine with permanent magnet excitation [15]. There are also a number of hybrid systems. Clipper Windpower (after research into systems with multiple induction generators) developed a system with an in- novative gearbox with ouputs to four permanent magnet generators (PMGs). Northern Power Systems (after initially adopting a wound rotor direct drive design) and GE Energy in their 2.5 XL series, have all adopted PMG systems.

Generator and gearbox of the vertical axis wind turbines can be placed near the ground, hence avoiding the need of a tower and improving accessibility for maintenance, figure 3 . Wind turbines of this type have low rotational speed with a consequential higher torque and higher cost of the drivetrain, lower power coefficient, but they don't need to be pointed into wind to be effective. There are several subtypes of vertical axis wind turbine such as Darrieus, Savonius wind turbine and giromill. Regarding offshore wind energy, currently, Europe is the world leader. As of 2010, there are no offshore wind farms in the United States. However, there are some projects under development. Siemens and Vestas are the leading turbine suppliers for offshore wind energy. Commercialscale offshore wind farms currently are similar to the onshore wind farms, but with modifications 


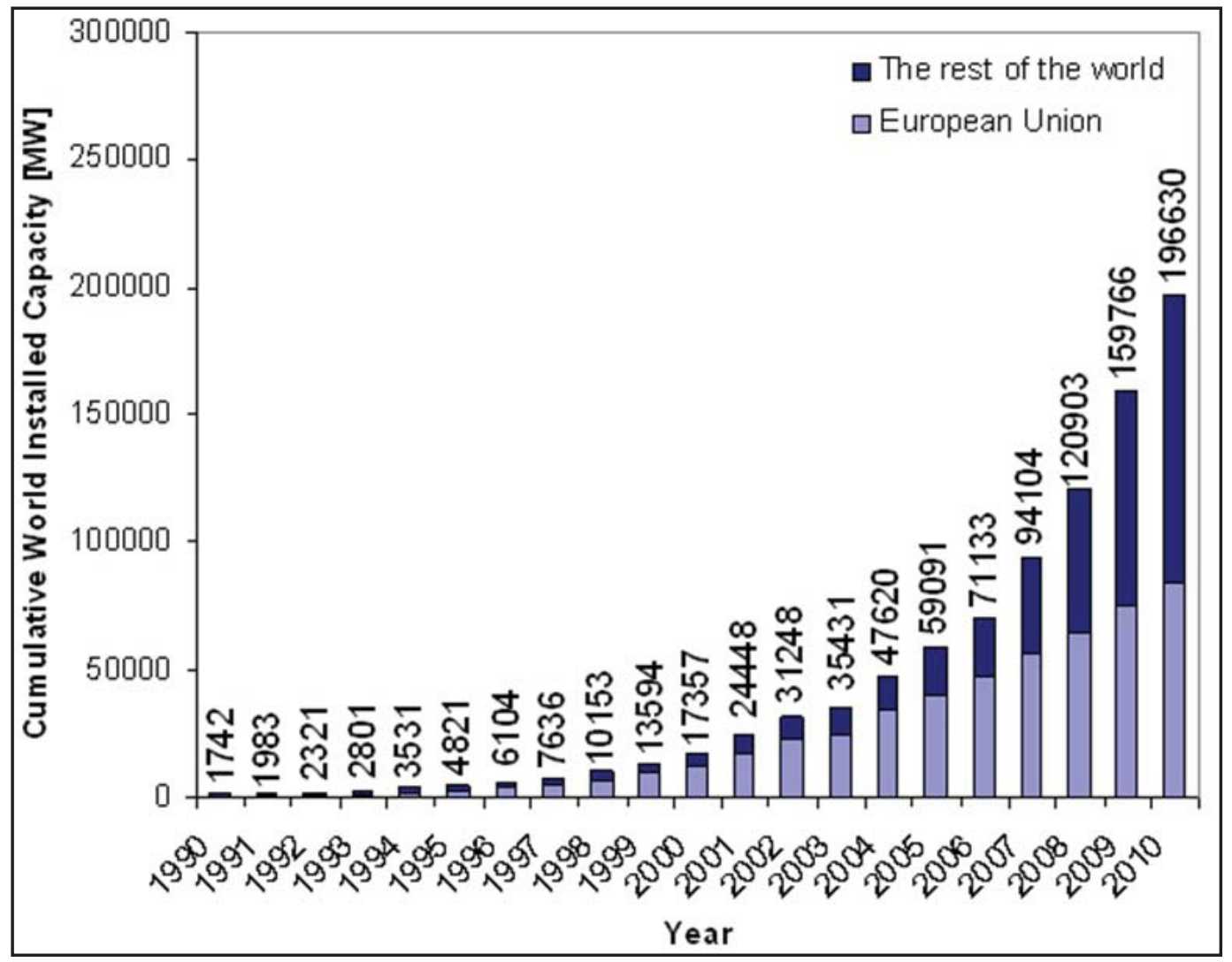

Figure 4. World wind energy capacities

(1990-2010)

to withstand higher wind loads, prevent corrosion and protect against wave and wind interactions. Offshore wind turbines are bottom founded (driven monopiles or conventional concrete gravity bases as foundations) or of the floating type. For large water depths and soft seabeds, floating wind turbines may be attractive due to a cheaper anchor installation than the cost of a fixed foundation. These floating foundations are mainly in research phase. Some of the proposed solutions are: spar-buoy, tension-leg platform, semi-submersible (column stabilized) and pontoon (barge) type [21]. The first grid-connected deep water floating wind turbine in the world is an Siemens Wind Power 2.3 called Hywind [14].

\section{GLOBAL WIND ENERGY MARKET}

In the last two decades the growth of the installed wind power capacities in the world was rapid. At the beginning of the 1990s there were $1742 \mathrm{MW}$ of installed wind turbines globally. In the early period of commercial utilization of wind power, wind turbines were mainly installed in Denmark and USA as the result of research efforts in these countries. USA expe- rienced a wind power expansion from 1982 to 1986 when thousands of Danish and American wind turbines were installed in massive arrays. As the wind power technology matured and awareness of renewable energy sources (RES) utilization grew, Europe overtook the leading role as the wind power market with the highest growth from the mid-nineties, figure 4. Denmark, Germany and Spain may be attributed as main drivers of high annual growth of wind power capacities during the period from 1990 until 2007.

Denmark was one of the key countries for wind power technology development. The knowledge acquired during the eighties based on commercially developed wind turbines up to $100 \mathrm{~kW}$ of rated power presented excellent basis for further research and development of megawatt wind turbines, which was implemented by strong collaboration between research institutions and interested companies with lasting support from the society. The main driver of the swift technology development was learning-by-doing, i.e. construction of demonstration and commercial wind farms. As early as 1999, Denmark had $1749 \mathrm{MW}$ of total wind energy capacities with more than 6000 wind turbines erected, which 
have presented $50 \%$ of capacities in 2010 . Onshore wind power capacities in Denmark from 1739 MW in 1999 grew to 2600 MW in 2003 and are in stagnation until present. In the same time, number of wind turbines has been reduced to 5000 in 2009. Future development of wind energy market in Denmark is oriented towards off-shore wind power utilization. Installed wind energy capacities in Denmark (3479 MW) can attribute roughly $20 \%$ of national electric energy consumption. Market maturity and high share of wind energy in overall energy capacities present good basis for transfer of the best practices from Denmark in terms of operation and maintenance of wind turbines, as well as wind power integration in national power system. Despite relatively small overall installed capacities comparing to other wind energy markets, Denmark remained one of the key countries in terms of exporting of wind power technologies and had great sig-

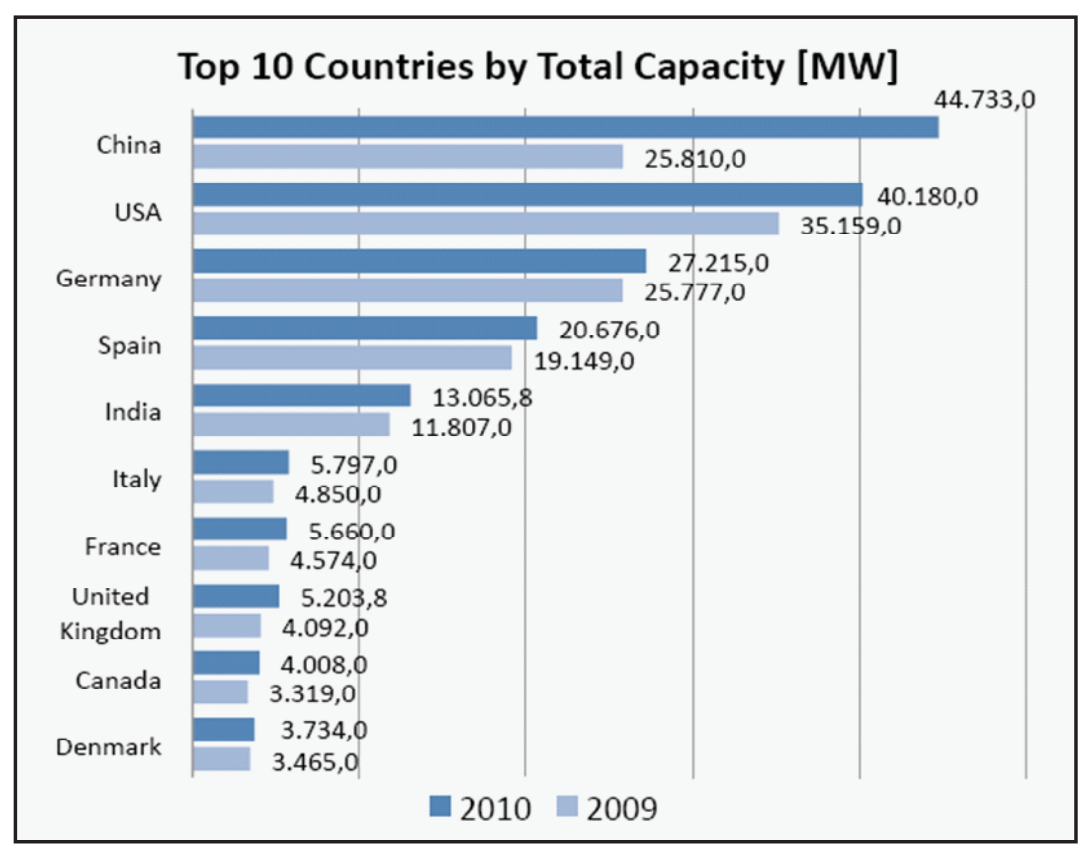

Figure 5. Countries with the largest cumulative wind power capacities (MW) [24]

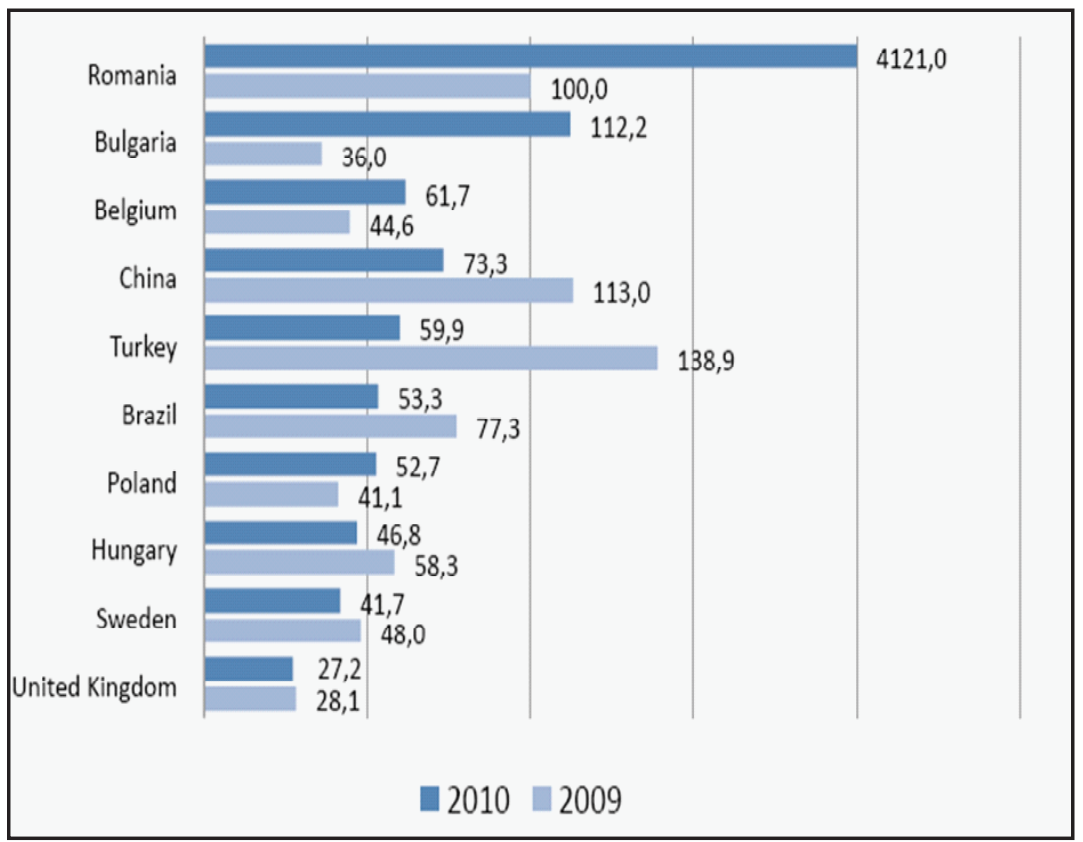

Figure 6. Countries with the highest growth of installed wind power capacities (\%) [24] 
nificance and impact on development of other national markets. Germany and Spain also had high wind power growth during the period between 1997 and 2008. In the early nineties several wind power companies emerged in Germany that had driven research and development efforts in order to commercialize wind power which later had impact on the global market. Wind energy in Germany in 1997 accounted for roughly 3000 MW, and at the end of 2008 there were 23903 MW of installed wind power with 21164 wind tur- bines. In the same period in Spain was installed $15906 \mathrm{MW}$ for total capacity of 16740 MW. Early development of the wind power market in Spain during mid-nineties is due to wind turbine import and technology transfer from Denmark. In the following years domestic companies overtook larger part of the market until the present. At the end of 2010 Spain had a total capacity of 20676 MW and Germany 27215 MW which accounted for $55 \%$ of European installed wind power capacities. It should be mentioned that

Table 1. Market share of top ten wind turbine manufacturers for period 2005-2010 [5]

\begin{tabular}{|l|c|c|c|c|c|c||}
\hline $\begin{array}{l}\text { Wind turbine } \\
\text { manufacturer }\end{array}$ & $\begin{array}{c}2005 \\
(11471 \mathrm{MW})\end{array}$ & $\begin{array}{c}2006 \\
(12042 \mathrm{MW})\end{array}$ & $\begin{array}{c}2007 \\
(23590 \mathrm{MW})\end{array}$ & $\begin{array}{c}2008 \\
(26180 \mathrm{MW})\end{array}$ & $\begin{array}{c}2009 \\
(38863 \mathrm{MW})\end{array}$ & $\begin{array}{c}2010 \\
(36864 \mathrm{MW})\end{array}$ \\
\hline Vestas & 27.9 & 27.4 & 23 & 17.8 & 12.5 & 14.8 \\
\hline Sinovel & $\mathrm{N} / \mathrm{A}$ & $\mathrm{N} / \mathrm{A}$ & 3.4 & 4.5 & 9.2 & 11.1 \\
\hline GE Wind & 17.7 & 15.3 & 16 & 16.7 & 12.4 & 9.6 \\
\hline Goldwind & 1.2 & 2.9 & 4.2 & 3.6 & 7.2 & 9.5 \\
\hline Enercon & 14.2 & 14.5 & 14 & 9.0 & 8.5 & 7.2 \\
\hline Suzlon & 6.1 & 7.5 & 10.5 & 8.1 & 6.4 & 6.9 \\
\hline Dongfang & $\mathrm{N} / \mathrm{A}$ & $\mathrm{N} / \mathrm{A}$ & $\mathrm{N} / \mathrm{A}$ & 3.4 & 6.5 & 6.7 \\
\hline Gamesa & 12.9 & 15.5 & 15.4 & 10.8 & 6.7 & 6.6 \\
\hline Siemens & 5.5 & 7.1 & 7.1 & 6.2 & 5.9 & 5.9 \\
\hline Nordex & 2.6 & 3.3 & 3.4 & 3.4 & $\mathrm{~N} / \mathrm{A}$ & $\mathrm{N} / \mathrm{A}$ \\
\hline Other & 11.9 & 6.5 & 3 & 16.5 & 24.7 & 21.7 \\
\hline
\end{tabular}

annual electricity generation in Germany in 2009 and 2010 was $38000 \mathrm{GWh}$ and $36500 \mathrm{GWh}$ respectfully, while in Spain 42976 GWh has been produced by wind power capacities in 2010 .

After US government adopted tax incentives for wind energy in 2004, substantial capacities were to be built in USA in the following years. From initial 9147 MW of installed wind power in 2005, the capacities were enlarged to $34863 \mathrm{MW}$ at the end of 2009 making USA country with the largest total wind power capacity in the world. In 2010 annual growth rate in USA was 15.25 $\%$ which is the lowest growth rate since 2004, resulted in total wind power capacities of 40180 $\mathrm{MW}$ at the end of 2010. Intensive wind power market growth was seen in China between 2005 and 2010, with annual growth around 100\%. Total installed wind power was increased from $1260 \mathrm{MW}$ in 2005 to $41800 \mathrm{MW}$ at the end of 2010, which made China the world largest wind energy market in 2010, figure 5. [24].
The markets in surrounding countries showed the signs of huge investments made in wind power for the last two years. Romania had total installed capacity of $591 \mathrm{MW}$ in 2010, with added $577 \mathrm{MW}$ in the previous year, figure 6 .

During the 2010 in Bulgaria was installed 198 MW of wind power for total capacity of 347.5 MW. Hungary has added 94 MW during 2010, with total capacity of $295 \mathrm{MW}$ at the end of 2010. It has been erected $43 \mathrm{MW}$ of new capacities in Croatia, for the total capacity of $69.8 \mathrm{MW}$ [24].

World market annual share of the leading wind turbine manufacturers has been shown for period between 2005 and 2010 in table 1. It can be noticed that eight largest wind turbine manufacturers were involved in production of at least $80 \%$ of the world's wind power capacities until 2009.

The individual manufacturers have chosen different ways to market success [02]. Vestas has been one of the world's leading manu- 
facturers of wind turbines. Vestas technology is generally particularly lightweight. Their innovation in nacelle systems design has contributed to this characteristic. Currently, Vestas is working on the development of a $7 \mathrm{MW}$ wind turbine. Siemens (along with Vestas) is among a few companies increasingly successful in the offshore wind energy market. Its 3.6 MW SWT turbines of $107 \mathrm{~m}$ diameter are now figuring prominently in offshore projects. The advanced technology used in Gamesa G1284.5 MW wind turbine makes for a more reliable system. Technological developments applied to improve reliability include load-reducing multivariable control, powertrain without the high- speed rotating components and modular electric power system which isolates the mechanical train from loads caused by voltage drops. Gamesa ranks among the world leaders in the market, having installed 20,834 MW until 2010 [11].

The Enercon E 40/500kW horizontal-axis turbine was the first system with a direct-drive generator to establish itself in the market with great success in a very short time. Today, Enercon has dominated supply of direct drive turbines [10]. Nordex is developing new control techniques and has a condition monitoring system, which monitors component wear, also incorporating ice sensors and an automatic fire extinguishing system.

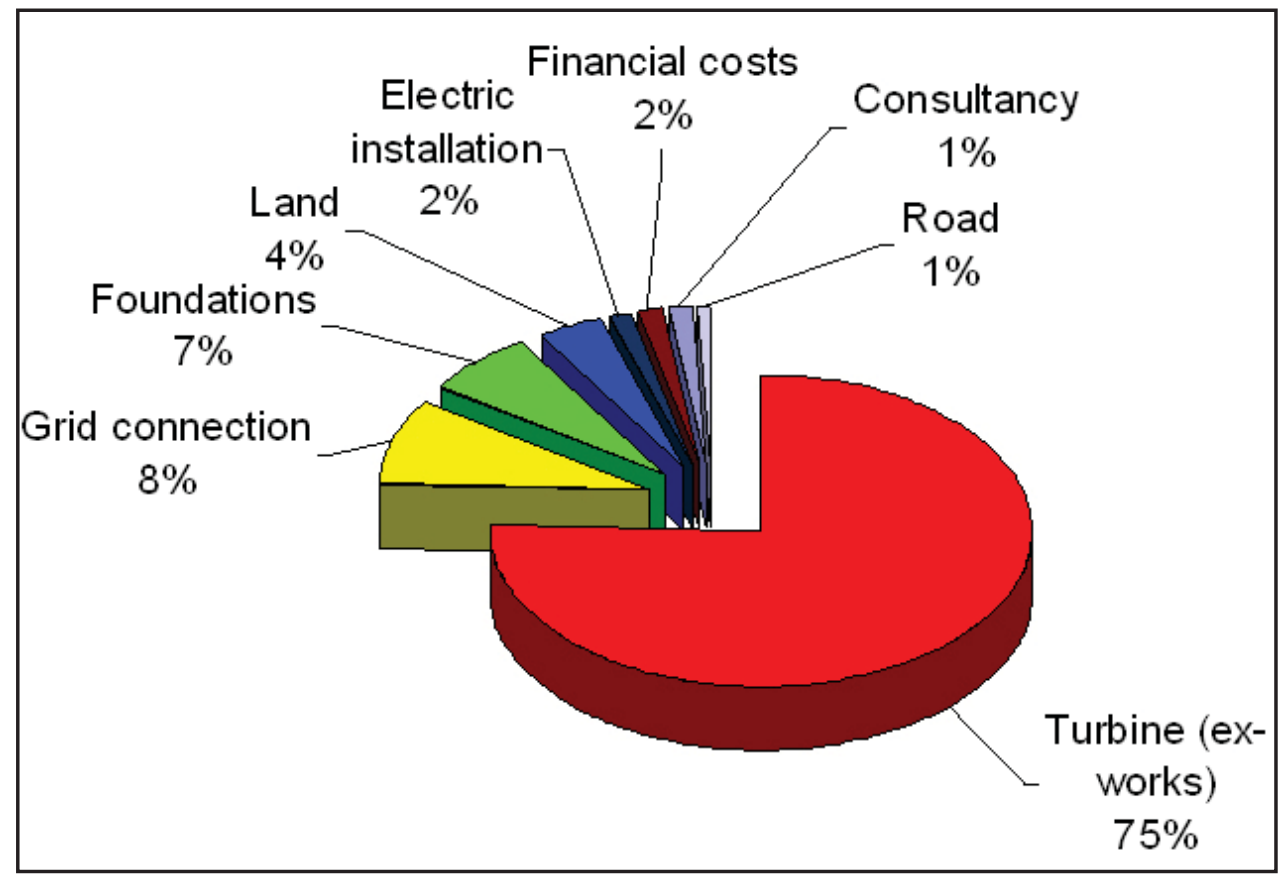

Figure 7. Breakdown of the capital costs

Manufacturers from EU have been dominating the world market for years, although with the expansion of markets in China during the last several years their shares were in decline as several local Chinese companies has developed own well established positions at national level, table 1. This was a consequence of the strong support for wind power from government with high incentives for wind power manufacturing related activities. Despite lower relative shares of well established wind turbine manufacturers such as Vestas, GE Wind, Enercon and Gamesa during 2009 and 2010, all of these companies had rapid growth in the production due to the growth of the world's wind power capacities (11471 MW were installed in 2005, while 36864
MW were installed during 2010). The forecasts are made that until 2020 the global capacity will be close to one terawatt, and present capacities of the leading manufacturers will be in expansion, as well as newly established manufacturing companies. One of the indicators of intensified activities in the wind power manufacturing sector is the growth of the market share that was held by smaller and emerging wind power companies. Almost one quarter of the world market was held by such manufacturers in 2009 which is more than double comparing to 2005.

\section{WIND ENERGY COSTS}


The cost of electricity produced by wind turbines consist of investment (capital) costs and cost due to operating and maintenance. The investment costs include initial costs of the project such as feasibility study cost, the cost of project management including acquiring all necessary permits, wind turbines procurement, civil works, electrical infrastructure, grid connection, installation and other costs (insurance cost, bank fees etc.). Breakdown of the capital costs according to [7] is shown in fig. 7.Although there are variations in the capital cost structure introduced in the existing literature, there are certain trends that are widely confirmed. Capital costs account for more than $80 \%$ of all costs for a wind farm during lifetime. The larger part of the capital cost is due to wind turbine procurement. According to several sources [03], [18] at least $70 \%$ of capital cost is due to wind turbine procurement excluding works (transportation is included in the price).

Other capital costs such as grid connection, civil works and installation costs are highly dependent on location of the wind farm. Factors such as the local legislative framework for obtaining operating permits, grid connection availability and type (distributive or transmission grid), soil structure, availability and the cost of local labor and machinery influence on other capital costs.

The capital costs vary from 1200 euros per $\mathrm{kW}$ of rated power to 1850 euros per kW for onshore wind farms. The unit price for off-shore wind power plants can be substantially higher.
After the steady decay of wind turbine costs from 1980s until 2000s, from 2005 the growth of investment costs has been observed. It should be pointed out that the capital costs in Europe (more specifically in European Union), USA and China and other markets in Asia are notably different, as well as wind turbine procurement costs.

Operation and maintenance (O\&M) costs are variable costs that are usually expressed in term of the fraction of the produced electricity price. They comprise of costs for regular maintenance, repair, spare parts, insurance, taxes, management, administration, land rental and grid integration costs.

According to [07] O\&M costs could have share of $20-25 \%$ of total levelised costs per produced $\mathrm{kWh}$ over the lifetime of the turbine. Based on the experience in the leading European markets, O\&M costs are generally estimated to be between 1.2 and $1.5 \mathrm{c} € / \mathrm{kWh}$ of power produced over the total lifetime of wind farm (wind turbine). Usually, wind turbines have warranty period for two to three years. In this period the maintenance cost can be as low as 0.3-0.4 c€/kWh. For older turbines it is reported that this cost can be between 0.6 and $0.7 \mathrm{c} € / \mathrm{kWh}$. It has been reported that average O\&M costs could vary from $1.5 \mathrm{c} € / \mathrm{kWh}$ to $2.6 \mathrm{c} € /$ $\mathrm{kWh}$ [16]. It must be pointed out that this mentioned values are based on the data mainly consisted of wind turbines that are no more than ten years in operation. This variable cost is augmented during the operating lifetime. Some means of

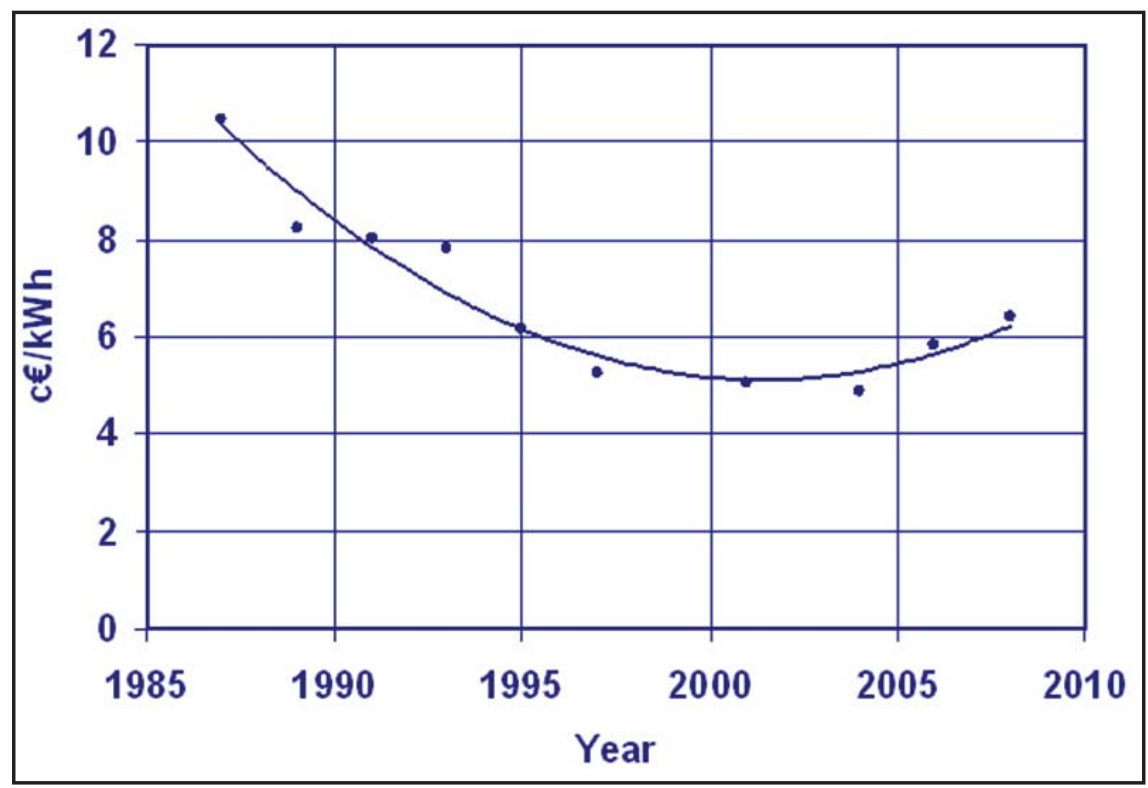

Figure 8. Wind energy costs per kWh of produced electricity 
reducing $\mathrm{O} \& \mathrm{M}$ costs through wind turbine condition monitoring system were described in [20].

On contrary to conventional fossil fuel-fired power plants, where $40-60 \%$ of total costs are related to the fuel and O\&M costs, wind energy is capital intensive with more than $70 \%$ of production costs, as mentioned, accounted to initial investment, i.e. capital costs. Therefore, the cost of capital (interest rate) is an important factor that influences the overall cost of wind-generated power. The total cost per kWh produced is usually calculated by discounting and levelising investment and O\&M costs over the lifetime of the turbine. In order to obtain the price per kWh of produced electricity it is necessary to predict annual electricity production. One of the methods is to estimate capacity factor of a wind turbine according to available wind resource which is considered to be representative over the wind turbine lifetime. Capacity factor is defined as the ratio of the calculated annual energy production and energy that would be produced if the wind turbine would operate at rated power over the whole year. System operators are faced with the challenges in order to maintain system stability, as wind energy share increase in overall energy portfolio of energy systems and emerging balancing costs. Although there are options for balancing of wind power plants output, which are highly variable but predictable to certain extent, practical solutions are the field of wide research in which must be included wind project owners, system operators and other utility companies [22]. European wind energy association (EWEA) published [7] that calculated costs per kWh of wind-generated electricity range from 8 to 11 $\mathrm{c} € / \mathrm{kWh}$ at sites with low average wind speeds (with capacity factor lower than 18\%) to approximately 5-7 $c € / \mathrm{kWh}$ at windy coastal sites with capacity factor between 30 and $33 \%$. The average cost of electricity produced from wind energy is $7 \mathrm{c} € / \mathrm{kWh}$ according to EWEA, which should be related to capacity factor around $25 \%$.

Wind energy costs per unit of electricity produced gradually decreased from mid-eighties until 2000s, fig. 8. The average total cost has decreased from $9.5 \mathrm{c} € / \mathrm{kWh}$ to around $5 \mathrm{c} € / \mathrm{kWh}$. Cost decrease can be attributed to gradually increase in wind turbine capacity (from average $50 \mathrm{~kW}$ machines at the beginning of 1980s to average $1500 \mathrm{~kW}$ wind turbines in 2000s), acquired know-how and innovations in wind turbine design, gained experience by the wind turbine manufacturers, owners and grid operators and economy of scale. The trend of cost decrease lasted until early 2000s. Gradual cost increase that was observed after the 2005 in the world (or 2002. in USA according to [04]) led to approximately $20 \%$ costs rise. Some of the identified reasons for higher costs are due to a continual high demand for new wind turbines, constraints in the supply chain in the delivery of turbine components, the price growth of raw materials and even higher profit share of manufacturers. The gradual cost decrease trend is expected to continue in 2012, but with lower rate than the previous trend at the end of 20th century.

\section{CONCLUSION}

Wind power industry had high growth in the last decade. Steady growth during the next ten years is anticipated. Current installed capacities of nearly $200 \mathrm{GW}$ should grow to almost one terawatt until 2020. Rapid technology development was initiated by researches led by several institutions in Europe and USA, such as Risoe - Danish Technical University (Risoe DTU), Energy research Centre of Netherlands (ECN), Fraunhofer, Deutches Windenergie Institut (DEWI) and National Renewable Energy Laboratory (NREL) during the eighties and nineties of the twentieth century. With commercialization of the wind power technologies during early nineties, manufacturers significantly contributed to industry development as the reduction of the price of produced energy was the main driver of research activities. Modern on-shore wind turbines became large structures with good reliability tailored to specific wind sites and operating conditions. Current research trends are oriented towards manufacturing of even larger wind turbines with more than $7 \mathrm{MW}$ of rated power. This trend corresponds to exploitation of off-shore wind resources, for which there are still many barriers that remain to be overcome in the future. Nevertheless, there is a space for further improvement of current mainstream on-shore technologies, such as rotor load alleviation using novel materials and load control methods, further improvements of reliability and availability, mass reduction, integration in power systems etc. Dynamic global wind power market is mainly driven by utilization of the best available wind sites and government incentives both for man- 
ufacturing and installation of wind turbines and wind farms. EU remained the biggest wind power market during early 2000s (particularly markets in Germany and Spain). With adoption of wind power incentives in China and steady development of national manufacturers and wind farms between 2005 and 2010, the new market expanded taking leading role in annual installed capacities in 2010. During the same period the wind power industry regained momentum in USA. With all mentioned above, installed capacities were more than doubled in four years: from 2007 until 2010 wind power capacities grew from $94104 \mathrm{MW}$ to $196630 \mathrm{MW}$. After the steady price reduction of electricity produced by wind power from 1980s until early 2000s, the price has began to increase due to high demand for wind turbines and price growth of base materials. It is expected that the wind turbine price will gradually be reduced to the level from 2002 until 2013. Wind power technology improvements and better grid integration should attribute to the costs reduction. High wind turbine demand predictions, rapid technology and market growths are some of the indicators that should alert the public and private sector for broader involvement of available capacities in order to acquire necessary skills for wind power utilization and manufacturing, including participation in supply chains of large wind turbine manufacturers.

\section{ACKNOWLEDGEMENT}

This paper is a contribution to the research TR 35035 "Research and Development of Advanced Design Approaches for High Performance Composite Rotor Blades", that has been funded by Ministry of Education and Science of Republic Serbia.

\section{REFERENCES}

1) Ackermann T, Lennart S. (2000) Wind energy technology and current status: a review, $\mathrm{Re}$ newable and Sustainable Energy Reviews 4 (4), 315-374.

2) Avis M., Maegaard P. (2008), Worldwide Wind Turbine Market and Manufacturing Trends, Denmark: Folkecenter.

3) Blanco M. (2009), The economics of wind energy, Renewable and Sustainable Energy Reviews 13 (6-7), 1372-1382.
4) Bolinger M., Wiser R., (2009). Wind power price trends in the United States: Struggling to remain competitive in the face of strong growth. Energy Policy 37 (3), 1060-1071.

5) BTM Consult (2011), International Wind Energy Development: World Market Update 2010, Denmark: BTM

6) Det Norske Veritas and Wind Energy Department, Risoe National Laboratory (2002), Guidelines for Design of Wind Turbines, Second Edition, Denmark: Jydsk Centraltrykkeri

7) European Wind Energy Association (2009), Wind Energy-The Facts, UK: EWEA

8) European Wind Energy Association (2011), Upwind: Design limits and solutions for very large wind turbines, Brussels: EWEA

9) Global Wind Energy Council (2011), Global wind energy report 2010, Brussels: GWEC

10) http://www.enercon.de/en-en/767.htm retrieved on July 2nd, 2011

11) http://www.gamesa.es/en/gamesaen/, retrieved on July 2nd, 2011

12) http://www.iea.org/statist/index.htm, retrieved on June 20th , 2011

13) http://www.nordex-online.com/en/productsservices/wind-turbines/n80-25-mw/technical-drawing.html?type $=98 \& \% 3 \mathrm{BL}=2$, retrieved on June 2nd , 2011

14) http://www.powermag.com/renewables/ wind/Top-Plants-Hywind-Floating-WindTurbine-North-Sea-Norway_2305.html, retrieved on June 22nd, 2011

15) http://www.vensys.de/energy-en/technologie/generator-pm-technologie.php retrieved on June 15th, 2011

16) http://www. windpowermonthly.com/ news/1010136/Breaking-down-cost-wind-turbine-maintenance/, retrieved on July 2nd , 2011

17) http://www.wwindea.org/technology/ch01/en/1_ 2_3_2.html, retrieved on July 15nd, 2011

18) Junginger M. (2007), Learning in onshore and offshore wind energy technology development, International workshop on technology learning and deployment, International Energy Agency

19) Klaassen G., Miketa A., Larsen K., Sundqvist 
T. (2005), The impact of R\&D on innovation for wind energy in Denmark, Germany and the United Kingdom, Ecological Economics, 54 (2-3), 1227-1240.

20) Milovančević M., Anđelković B. (2010), Modern techniques of wind turbine condition monitoring. Applied Engineering Science, 8 (1), 33-38.

21) Wang C.M., Utsunomiya T., Wee S.C., Choo Y.S. (2010) Research on floating wind turbines: a literature survey, The IES Journal Part A: Civil \&Structural Engineering; 3(4), 267-277.
22) Weigt H. (2009), Germany's wind energy: The potential for fossil capacity replacement and cost saving, Applied Energy 86 (10), 1857-1863.

23) Welch J. B., Venkateswaran A. (2009) The dual sustainability of wind energy, Renewable and Sustainable Energy Reviews, 13 (5), 1121-1126.

24) World Wind Energy Association (2011), World Wind Energy Report 2010, Bonn: WWEA Head Office

Paper sent to revision: 19.10.2011.

Paper ready for publication: 23.11.2011. 